\title{
K-Ar DATING OF A BASALTIC LAYER IN THE SEDIMENTARY LAVRAS BASIN, NORTHEASTERN BRAZIL
}

\author{
H.N.A. PRIEM*, N.A.I.M. BOELRIJK*, R.H. VERSCHURE*, E.H. HEBEDA*, \\ E.A.TH. VERDURMEN* and E.H.BON**
}

\begin{abstract}
The Lavras basin near Lavras da Mangabeira (Ceará, NE. Brazil) is a relatively small tectonic basin filled with non-metamorphic sediments resting on the Precambrian/Cambrian crystalline basement. K-Ar dating of six samples from an intercalated basaltic layer yields an age of $175 \pm 4 \mathrm{Ma}$, setting an age about the Early/Middle Jurassic boundary to the sedimentation.
\end{abstract}

RESUMO A bacia de Lavras, perto de Lavras da Mangabeira, Ceará, é uma bacia tectônica relativamente pequena, contendo sedimentos não-metamórficos repousando sobre o embasamento cristalino precambriano/cambriano. A datação K-Ar de seis amostras de uma camada basáltica intercalada resultou numa idade de $175 \pm 4 \mathrm{Ma}$, comprovando uma idade ao redor do limite Jurássico Inferior/Médio para a sedimentação.

INTRODUCTION GEOLOGIC SETTING Parts of the crystalline basement of northeastern Brazil (the Precambrian Shield and intrusive granites of Cambrian age, Cordani 1974) are covered by sequences of non-metamorphic Paleozoic and/or Mesozoic to Tertiary sedimentary rocks, both in fault-bound basins and as plateaux. Correlation of the sedimentary rock units from one area to another is hampered by the scarcity of horizons containing sufficient diagnostic fossils and by the variations in lithology and thickness. This study deals with the Lavras Basin near the town of Lavras da Mangabeira in southeastern Ceará, one of a number of relatively small basins between the sedimentary successions of the Araripe Plateau in the South and the Iguatu Basin in the North (Fig. 1).

The oldest sediments in the Araripe Plateau are conglomeratic sandstones of presumably Devonian age (Beurlen 1970). They are overlain by the Araripe Group, a sedimentary sequence with a total thickness of about 800 meters and consisting of a lower sandy, a middle marly and an upper sandy part (Beurlen 1971). The lower part (Missão Velha Sandstone) is made of sandstones, often cross-bedded and containing thin beds of conglomerates and claystones. The middle part (Santana unit) comprises shales, limestones, marls and gypsum beds; it is famous for the well-preserved fish fauna of Aptian age (Santos and Valença 1968). Beurlen (1971) assigns an Aptian age to the whole sedimentary sequence above the conglomeratic sandstone, up to and including the Santana unit, but Braun (1966) correlates both the Missão Velha Sandstone and the lower part of the Santana unit ("Crato Member") with fossiliferous Middle to Late Jurassic sediments in the Tucano-Jatobá Basin, some $300 \mathrm{~km}$ to the South. The upper part of the Araripe Group consists of sandstones, often cross-bedded and presumably of Albian age (Exu Sandstone).

* Z.W.O. Laboratorium voor Isotopen-Geologie, De Boelelaan, 1085, Amsterdam-1011

** Billiton International Metals B.V., Louis Couperusplein 19, 's-Gravenhage 


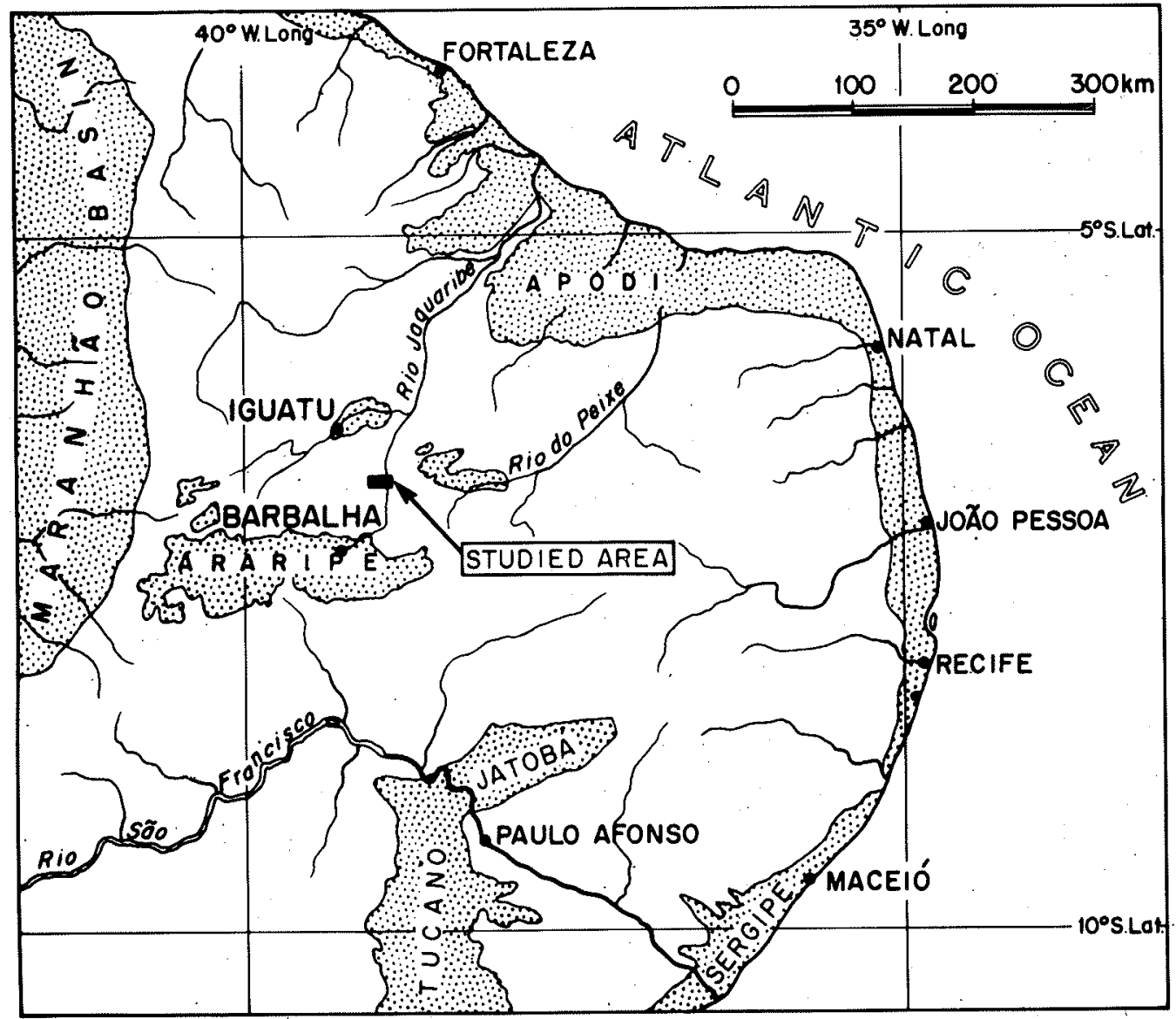

FD MAJOR OCCURRENCES OF NON-METAMORPHIC SEDIMENTS

CRYSTALL INE BASEMENT

Figure 1 - Northeastern Brazil with location of the studied area

A sedimentary sequence similar to the Araripe Group was deposited in the Iguatu Basin, the Iguatu Group with a total thickness of about 1,000 meters (Beurlen 1970). This succession likewise has a threefold division, in upward order crossbedded sandstones, argillites with local intercalations of marly and gypsiferous beds, and cross-bedded sandstones interbedded with conglomeratic beds and horizons rich in iron oxides. Fossils have not been reported, but Beurlen (1970) correlates the Iguatu Group on lithological grounds with the Araripe Group, a correlation which is supported by lithologic similarity with the sediments in the small Lavras and Barro Basins located between Iguatú and Araripe.

THE LAVRAS BASIN The Lavras Basin is situated in the sourthern part of the state of Ceará, northeastern Brazil, near the town of Lavras da Mangabeira (Fig. 2). It consists of two interconnected, half-moon-shaped patches of sedimentary rocks 
covering an area of some 70 square kilometers. Morphologically the patches are expressed as relatively low-lying, rather flat areas, where the alluvial deposits of traversing creeks suddenly expand over much wider extent than up and downstream. These fluviatile sediments are flanked by sequences of sedimentary rocks of predominantly sandy nature, reaching a maximum elevation of some 100 meters above creek level in the northwestern part of the basin.

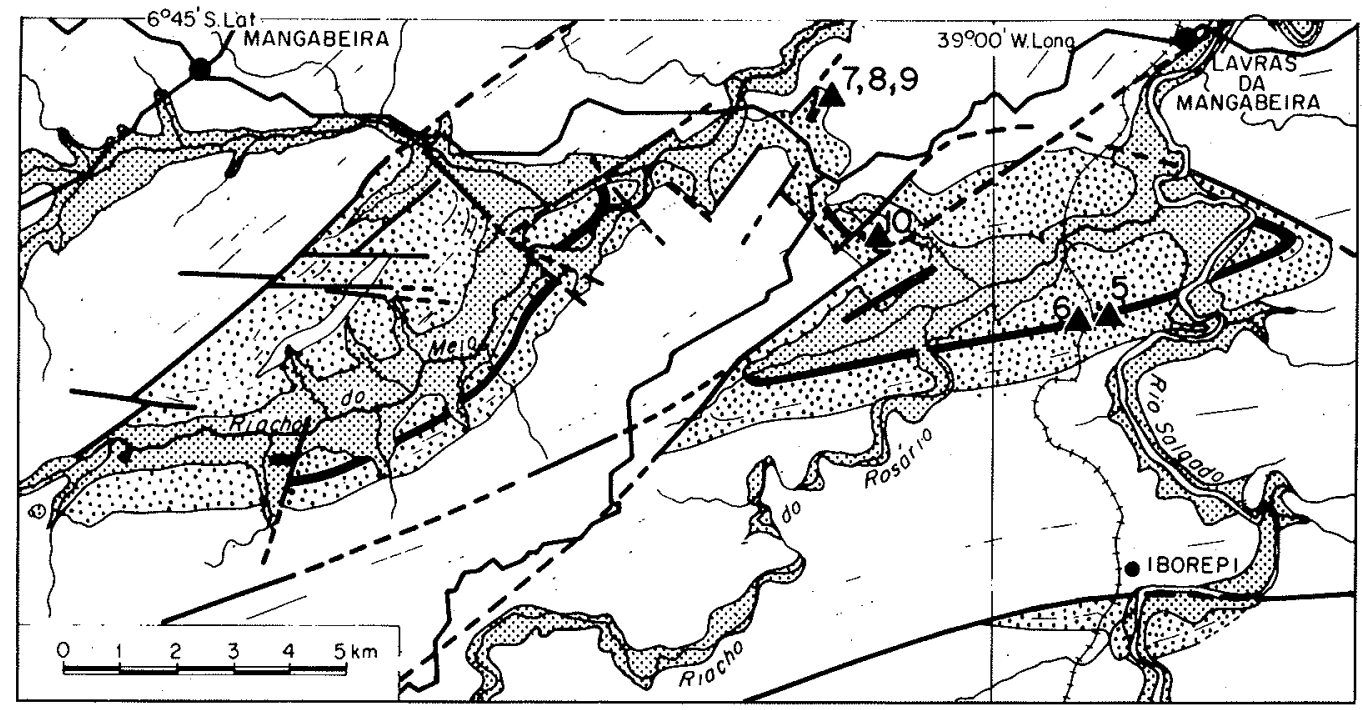

ALLUVIUM

$\because \therefore \because$ LAVRAS SEDIMENTS

- structural direction

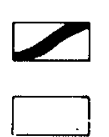

BASALT

CRYSTALLINE BASEMENT

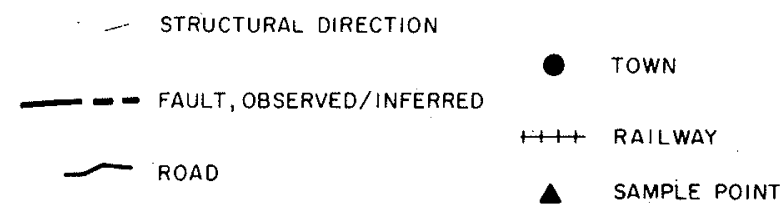

Figure 2 - Geological sketch map of the Lavras Basin, southeastern Ceará, Brazil (modified after Bon, 1962)

At the base of the sedimentary sequence a layer of cross-bedded sandstones occurs, in some places alternating with or substituted by variegated clays. A basaltic layer is intercalated in the sedimentary column at 15 to 35 meters above its base. The basalt is encased in variegated clays. Its thickness varies between 1 and 8 meters. No immediate contact with the encasing sediments has been observed, but the areal extension of the basalt shows that it is concordant or nearly so with the stratification of the sediments. The upper part of the sedimentary succession consists of laminated sandstone beds alternating with clays and marls and an occasional conglomeratic bed. Fossils are generally absent, except for shark teeth and fish scales in some sandstone layers and a few undeterminable clasts of bivalves. The maximum thickness of the sedimentary infill of the basin is probably about 80 meters. In the northwestern part southward dips of up to $50^{\circ}$ were measured. Elsewhere the dips vary between sub-horizontal and $10^{\circ}$ North. 
In the studied area another small wedge of sedimentary rocks occurs a few kilometers to the south of Lavras da Mangabeira, near the village of Iborepi. It has an E-W extension of about $5 \mathrm{~km}$ and a width not exceeding $2 \mathrm{~km}$. The sediments include clays and variegated marls containing fine gypsum layers. At the base a layer of sandstone occurs. The maximum thickness of this deposit does not exceed 40 meters. The layers dip 20 to $30^{\circ}$ North.

Vertical to sub-vertical faults form the northern margins of these sedimentfilled depressions. The southern limit of the sedimentary cover is erosional. The basins show a marked conformity to the structure of the surrounding basement: the axes of the basins are parallel to the trend of the major border faults, which, in their turn, are roughly parallel to the foliation and schistosity of the basement. In its western part the Lavras Basin is broken up into a number of blocks by a complex system of cross-cutting faults.

THE BASALT Six basalt samples were collected from unweathered, fresh spheroids for K-Ar dating. The locations are shown on Fig. 2 . In hand specimen it is a dark green rock in which up to $2 \mathrm{~mm}$ long crystals of feldspar and pyroxene are clearly discernable. Microscopically the rock has a sub-ophitic texture. Plagioclase and augite, in about equal proportions, are the main components. The plagioclase forms subhedral, tabular crystals showing a normal zoning from bytownite $\left(\mathrm{An}_{80}\right)$ to andesine $\left(\mathrm{An}_{4}\right)$ ). The augite crystals are euhedral to subhedral and prismatic. Magnetite, partially replaced by hematite, is a minor component. Turbid, brownish masses of albite, iron ore, celadonite and some anatase occur between the plagioclase and augite crystals, probably representing devitrified glass. A characteristic feature of the rock is the abundance of equidimensional masses, up to $2 \mathrm{~mm}$ in diameter, consisting of intergrown calcite, natrolite and celadonite; they probably represent original vesicular features.

The celadonite has a fibrous and felted appearance and is seen to merge with a brownish material of similar habit which, unfortunately, could not be isolated by microdrilling for X-ray identification (Verschure 1978), but is probably vermiculite (French et al. 1977). The secondary minerals in this basalt appear to indicate lowtemperature hydrothermal conditions at the final stage of volcanic activity.

K-Ar DATING Sieve fractions. $(-250+125 \mu \mathrm{m})$ of six whole-rock basalt samples were analysed according to the K-Ar method. Potassium was analysed by flame photometry with lithium internal standard and CsAl buffer. Argon was extracted in a bakeable glass vacuum apparatus and determined by isotope dilution techniques (using ${ }^{3}{ }^{8} \mathrm{Ar}$ as a tracer) in a Varian GD-150 mass-spectrometer; all measurements were made by the static method. The analytical errors are estimated to be within $2 \%$ for $\mathrm{K}$ and $\mathrm{Ar}$ each. The following constants were used for the age calculations: $\lambda_{\mathrm{e}}=0.581 \times 10^{-1}{ }^{0} \mathrm{a}^{-1}, \lambda_{\beta}=4.962 \times 10^{-1}{ }^{0} \mathrm{a}^{-1}$ and abundance ${ }^{40} \mathrm{~K}=0.01167$ atom percent total $\mathrm{K}$ (Steiger and Jäger 1977).

In Table 1, the analytical results and calculated ages are listed. The six $\mathrm{K}-\mathrm{Ar}$ dates appear to be concordant at $175 \pm 4 \mathrm{Ma}$. This age is taken as approximating the age of extrusion. Following the time-scales proposed by Lambert (1971) and van Hinte (1976), the extrusion of the basalt may thus be placed near the boundary between the Early and Middle Jurassic, approximately in the Aalenian (uppermost part of the Early Jurassic). 
Table 1 - K·Ar data Lavras basalts

\begin{tabular}{|c|c|c|c|c|}
\hline $\begin{array}{l}\text { Sample } \\
\text { Nr. }\end{array}$ & $\stackrel{\mathrm{K}}{(\% \mathrm{Wt})}$ & $\begin{array}{l}\text { Radiogenic }{ }^{40} \mathrm{Ar} \\
\quad(\text { ppm Wt })\end{array}$ & $\begin{array}{c}\text { Atmospheric }{ }^{40} \mathrm{Ar} \\
\left(\% \text { total }{ }^{40} \mathrm{Ar}\right)\end{array}$ & $\begin{array}{c}\text { Calculated age* } \\
(\mathrm{Ma})\end{array}$ \\
\hline 73 Bar 5 & $\begin{array}{l}0.999 \\
1.005\end{array}$ & $\begin{array}{l}13.14 \times 10^{-8} \\
12.98 \times 10^{-3}\end{array}$ & $\begin{array}{l}16 \\
15\end{array}$ & 179 \\
\hline 73 Bar 6 & $\begin{array}{l}0.762 \\
0.767\end{array}$ & $\begin{array}{l}9.90 \times 10^{-8} \\
9.65 \times 10^{-3}\end{array}$ & $\begin{array}{l}16 \\
40\end{array}$ & 176 \\
\hline 73 Bar 7 & $\begin{array}{l}0.774 \\
0.774\end{array}$ & $\begin{array}{l}10.25 \times 10^{-8} \\
10.04 \times 10^{-8}\end{array}$ & $\begin{array}{l}51 \\
15\end{array}$ & 180 \\
\hline 73 Bar 8 & $\begin{array}{l}0.731 \\
0.732\end{array}$ & $\begin{array}{l}9.17 \times 10^{-8} \\
9.21 \times 10^{-3}\end{array}$ & $\begin{array}{l}18 \\
19\end{array}$ & 173 \\
\hline 73 Bar 9 & $\begin{array}{l}0.841 \\
0.843\end{array}$ & $\begin{array}{l}10.30 \times 10^{-3} \\
10.42 \times 10^{-3}\end{array}$ & $\begin{array}{l}25 \\
62\end{array}$ & 169 \\
\hline 73 Bar 10 & $\begin{array}{l}0.747 \\
0.749\end{array}$ & $\begin{array}{l}9.68 \times 10^{-3} \\
9.20 \times 10^{-3} \\
9.40 \times 10^{-3}\end{array}$ & $\begin{array}{l}16 \\
45 \\
16\end{array}$ & 173 \\
\hline
\end{tabular}

* Errors estimated at $4 \%$.

DISCUSSION On the basis of their lithologic similarities, the Lavras Group may be correlated with the lower members of the Araripe Group and the Iguatu Group. The Early/Middle Jurassic age of the Lavras sediments should thus also apply to the corresponding horizons in the other two sequences. This supports Braun's (1966) correlation of the lower part of the Araripe Group with the Middle to Late Jurassic sediments in the Tucano-Jatobá Basin. Fig. 3 summarizes the time-rock divisions in the sedimentary columns of the Lavras, Araripe and Iguatu Basins and their correlation, as envisaged by one of us (E.H.B.).

The age of $175 \pm 4 \mathrm{Ma}$ of the basaltic in the Lavras Formations accords with the Late Triassic/Early Jurassic age assigned to the basaltic magmatism in the Maranhão and Amazon basins (Mesner and Woolridge 1964). Probably, this basaltic magmatism should be related to the breakup of Laurasia and Gondwanaland and the opening of the Atlantic Ocean. Seafloor spreading and lithosphere separation, with the generation of oceanic crust, started in earnest during the Early Jurassic, around $180 \mathrm{Ma}$ ago (Vogt 1973, Burke 1976), although rifting and the onset of tholeiitic extrusion may have started earlier, in the Triassic (Vine and Hess 1970). Basaltic magmatism from the Middle Triassic up into the Middle Jurassic appears to be a common phenomenon around the Atlantic, for example the basic dike swarms in Liberia (about 175 to $195 \mathrm{Ma}$, Dalrymple et al. 1975), the Foum Zguid dolerite dike system in Morocco (about 180 to $190 \mathrm{Ma}$, Hailwood and Mitchell 1971), several ba- 
sic sills and dikes intruding Late Triassic sediments in Morocco (about 185 to 225 Ma, Michard 1976, Cousminer and Manspeizer 1976), the Messejana dolerite dike system in the S.W. Iberian Peninsula (about 170 to $185 \mathrm{Ma}$, Schermerhorn et al. 1978), several basic dikes and sills in the Amazon Region (Thomaz Filho et al., 1974) and the Newark Group of basic lavas and intrusions in the eastern Appalachians of North America (about 175 to $200 \mathrm{Ma}$, Reesman et al. 1973); all K-Ar dates are recalculated with the new set of potassium constants used in this paper. According to May (1971), the systematic trends of the Triassic-Jurassic dolerite dikes around the North Atlantic indicate that they form a radial pattern caused by a stress field imposed on the continental crust by the mobile upper mantle prior to breakup.

Almeida (1969) also recognizes in the Brazilian Platform a Jurassic event of block-faulting, rifting and the formation of intracratonic basins, accompanied by extensive basic volcanism.

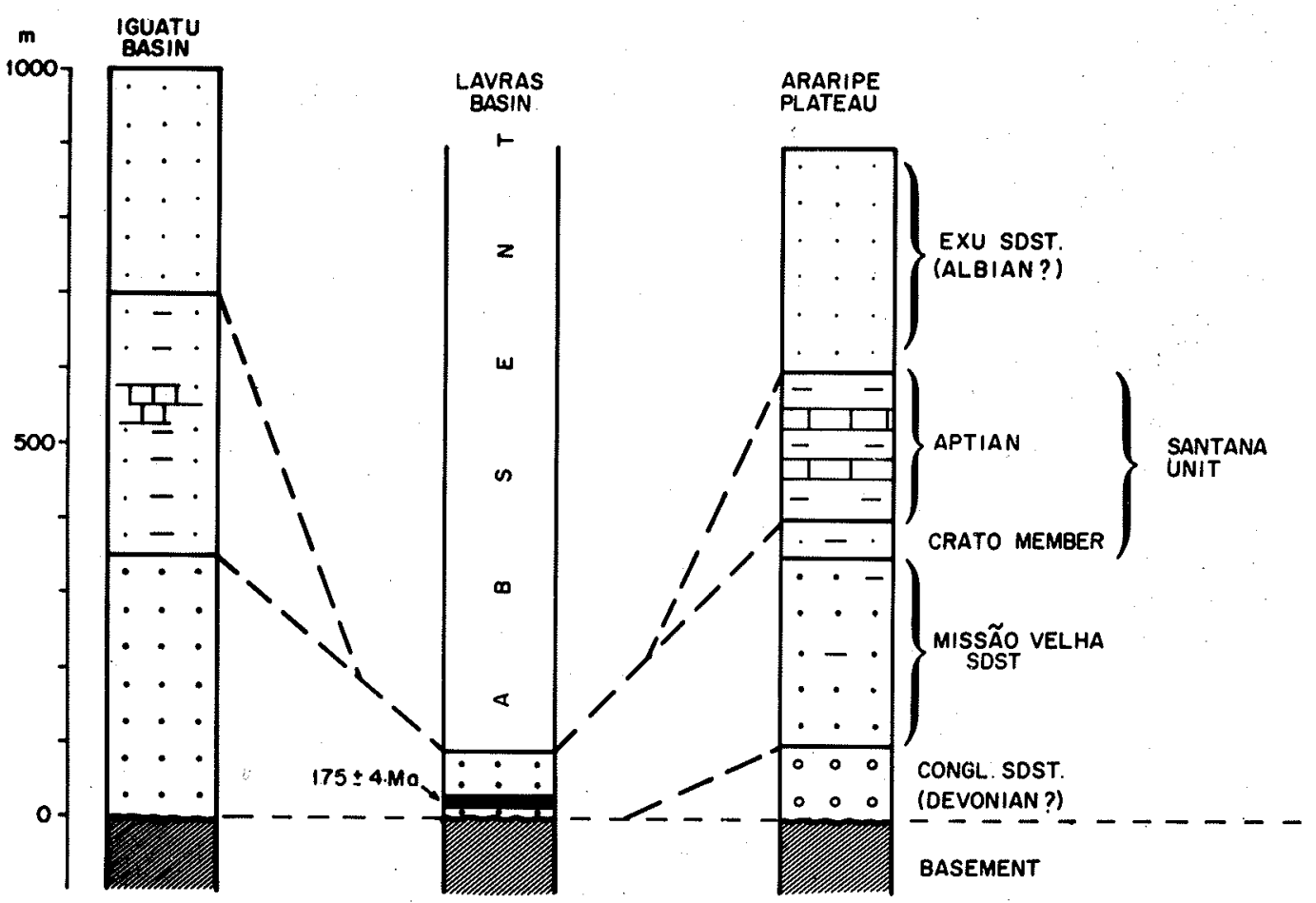

Figure 3 - Proposed correlation of the Lavras Formation with the Iguatu Formation and the Araripe Series

Acknowledgements The samples were collected during fieldwork by one of us (EHB), in connection with an economic mapping programme sponsored by Unesco/SUDENE in 1961/62. This dating work forms part of the research programme of the "Stichting voor Isotopen-Geologisch Onderzoek", supported by the Netherlands Organization for the Advancement of Pure Research (Z.W.O.) 


\section{REFERENCES}

ALMEIDA, F.F.M. de - 1969 - Diferenciação tectônica da plataforma brasileira: An. XXIII Congr. Bras. de Geologia, 1969: 29-46.

BEURLEN, K. - 1970 - Geologie von Brasilien, Beiträge zur regionalen Geologie der Erde 9: Bornträger, Berlin, Stuttgard, 442 pp.

BEURLEN, K. - 1971 - As condições ecológicas e faciológicas da Formação Santana na Chapada do Araripe (Nordeste do Brasil). An. Acad. brasil. Ciênc., 43, (Suplemento): 411.415.

BON, E.H. - 1962 - Relatório Preliminar sobre trạbalho geológico executado no sul do Ceará. Relatório Div. de Geologia, SUDENE (inédito).

BRAUN, O.P.G. - 1966 - Estratigrafia dos sedimentos da parte interior da região Nordeste do Brasil (Bacias de Tucano-Jatobá, Mirandiba e Araripe). DNPM/DGM.

BURKE, K. - 1976 - Development of graben associated with the initial ruptures of the Atlantic Ocean. Tectonophys., 36: 93-112.

CORDANI, U.G. - 1974 - Comentários sobre as determinações geocronológicas disponiveis nas folhas Jaguaribe e Fortaleza, in Carta Geológica do Brasil ao milionésimo, Folha Jaguaribe (SB-24)/Folha Fortaleza (SA-24). Texto Explicativo por J.R. Alcoforado Dantas, Brasília 1974, Apêndice, pp. 59-70.

COUSMINER, H.L. and MANSPEIZER, W. - 1976 - Triassic pollen date Mo occan High Atlas and the incipient rifting of Pangea as Middle Carnian. Science, 191: 943945.

DALRYMPLE, G.B., GROMMÉ, C.S. and WHITE, R.W. - 1975 - Potassium-argon age and paleomagnetism of diabase dikes in Liberia: initiation of central Atlantic rifting: Geol. Soc. America Bull., 86: 399-411.

FRENCH, W.J., HASSAN, M.D. and WESTCOTT, J.E. - 1977 - Celadonite-vermiculite series from the volcanic rocks of the Ochils, Stirlingshire. Miner. Mag., 41: 481-485.

HAILWOOD, E.A. and MITCHELL, J.G. - 1971 - Paleomagnetic and radiometric dating results from Jurassic intrusions in South Morocco. Geophys. J. Roy. Astr. Soc., 24: 351-364.

HINTE, J.E. van - 1976 - A Jurassic time scale. Am. Assoc. Petrol. Geol. Bull., 60: 489-497.

LAMBERT, R.St.J. - 1971 - The pre-Pleistocene Phanerozoic time-scale, a review, in The Phanerozoic time-scale, a supplement. Geol. Soc. London, special publ. No. 5: 932.

MAY, P.R. - 1971 - Pattern of Triassic-Jurassic diabase dikes around the North Atlantic in the context of predrift position of the continents. Geol. Soc. America Bull., 82: 1285-1292.

MESNER, J.C. and WOOLRIDGE, L.C.P. - 1964 - Maranhão paleozoic basin and Cretaceous coastal basins, North Brazil. Bull. Am. Assoc. Petrol. Geol., 48(9): 1475-1512.

MICHARD, A. - 1976 - Eléments de Géologie Marocaine. Notes Mémoires Serv. Géol. Maroc, No. 252, 408 p.

REESMAN, R.A., FILBERT, C.R. and KRUEGER, H.W. - 1973 - Potassium-argon dating of the Upper Triassic lavas of the Connecticut Valley, New England. Geol. Soc. America Abs. with Programs (Northeastern Sec.), 5: 211.

SANTOS, R. da S. and VALENÇA, J.G. - 1968 - A formação Santana e sua paleoictiofauna. An. Acad. brasil. Ciênc., 40(3): 339-360.

SCHERMERHORN, L.J.G., PRIEM, H.N.A., BOELRIJK, N.A.I.M., HEBEDA, E.H., VERDURMEN, E.A.Th. and VERSCHURE, R.H. - 1978 - Age and origin of the Messejana Dolerite fault-dike system (Portugal and Spain) in the light of the opening of the North Atlantic Ocean. Journ. Geol. (in press). 
STEIGER, R.H. and JÄGER, E. - 1977 - Subcommission on Geochronology: convention on the use of decay constants in geo - and cosmochronology. Earth Planet. Sci. Lett. 36: 359-362.

THOMAZ FILHO, A., CORDANI, U.G. and MARINO, O. - 1974 - Idades K/Ar de rochas basálticas da Bacia Amazônica e sua significação tectônica regional. An. XXVIII Congr. Bras. Geol., 6: 273-278.

VERSCHURE, R.H. - 1978 - A microscope-mounted drill to isolate microgram quantities of mineral from thin and polished sections. Miner. Mag. (in press).

VINE, F.J. and HESS, H.H. - 1970 - Sea-floor spreading, in Maxwell, A.E., ed., The Sea. Wiley-Interscience, New York and London, 4, pt. II: 587-622.

VOGT, P.R. - 1973 - Early events in the opening of the North Atlantic, in Tarling, D. H., and Runcorn, S.K., eds., Implications of Continental Drift o the Earth Sciences. Academic Press, London and New York, 2: 693-712. 